\title{
中小河川のダム群集合管理計画
}

\section{CENTRALIZED OPERATION CONTROL OF DAM GROUPS ON MEDIUM OR SMALL RIVERS}

高 橋 彌*

By Wataru TAKAHASHI

\begin{abstract}
From the viewpoint of the natural disaster prevention, the construction of dams on rivers may prove appreciable effects when the successful functioning of their control in groups is guaranteed.

In recent years, the construction and operation of dams, equipped with flood control facilities, under jurisdiction of prefectural governments are increasing in number on medium or small rivers.

With regard to the control procedures of the above-mentioned dam groups, presented herein is a paper on the research and planning of a system for a satisfactory functioning of the control of dams to obtain the security of basins, based on the analyses of the existing operation control procedures of dams.
\end{abstract}

Keywords : river planning, flood control, water resources, operation control of dam

\section{1. まえがき}

河川に建設されるダムは，専用ダムや治水・利水・親 水の機能を合わせ持つ多目的ダムがあり目的別にみても 多様である。

ダム建設事業主体は，建設省や各府県など多くの分野 にまたがっている.

本論文では，これらのうち治水上の機能を有し，しか も建設省の予算補助を受けて府県が建設し，管理を行っ ているいわゆる補助ダムを対象とする.

これらのほとんどは，中小規模の河川に建設され最近 その数を増しており，ダム個々に個別管理が行われてい る. ダムが増すにつれて個別管理ダムの数も増し，同時 に，いくつかの問題が生じている．そこで本論文では現 行管理内容を分析したうえで問題処理を可能とする方式 を考案し, 計画を立て, 過去の洪水に対してシミュレー ションを行い, その計画が適切であることを検証するも のである.

\section{2. 課題および現状分析}

補助ダム建設完了数は昭和 30 年には全国で 20 であっ

* 正会員 工博 千葉工業大学教授 土木工学科 （テ275 習志野市津田沼 2-17-1）
た。それが昭和 40 年には 53 となり，60 年には対 40 年 比でおよそ 4 倍の $197^{1,2)}$ になっている. 管理ダムが急 増するにつれて生じている問題点は次のようなものがあ る.

\section{（1）問 題 点}

数多い夕゙ム管理所の統轄は県の水防本部のおかれてい る県庁の河川担当課に置かれているケースが多い，

そこで，(1)降雨とそれに起因する洪水は，通常，数個 のダム，ならびに相当数の河川に影響を及ぼすような一 定の広さの地域にほぼ同時に発生する。このため, 洪水 に際して定時連絡，洪水情報連絡等は一時に集中する。 したがって県本部では各河川の洪水に対応する必要が生 じ，各ダムに対して集中的な対応ができない。（2)県本部 より遠隔の地にあるダムは，事故，故障，長時間の異常 洪水等に対する処置，応援など即応しにくいケースが出 る. (3)山岳地と平地部，あるいは県東部と県西部など地 域によって異なる降雨状態が発生した場合, 各地に点在 するダムの情況把握には困難がある．(4)管理職員の増加 と技術, 熟練度については, ダム操作規則にそうような 雨ばかりでないうえに，洪水時の主ゲート操作を必要と する規模の降雨は通常年 1 2 回発生する程度である. この程度の機会にしか経験を積むことができない情況下 で，短時日に管理職員を育成することは難しい。（5)ダム 
管理職員の構成は，ほとんどが土木技術者である．情報， 計測, 操作, 連絡等機械化している現在, それに適合し た職種の技術者の配置が望まれている.

これら諸事項が原因となって生ずる危険性については ダムのもつ重要さからして看過し得ないものである.

著者は, 次の手順により検討を進め, 前述の問題点解 消のため, 新しいシステムの計画化を図るものである.

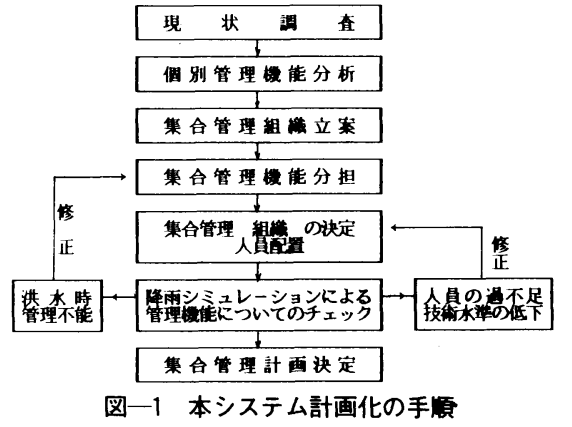

（2）個別管理の分析

補助ダム管理は「建設省河川砂防技術基準（案)」あ るいは，建設省河川局監修「多目的ダムの建設」3)等に 基づいて各ダムに適応した操作規則を作成し運用してい る. ダムごとに行っている個別管理の内容は次のとおり である。

a) 管理業務の内容

大別すると, 洪水時 2 項目，平常時 2 項目になる．す なわち, 洪水時には, (1)洪水調節, (2)洪水時に発生する 不測の事態に対する処理行動である.また, 平常時には, (1)関連水利施設への水門操作, (2)ダム本体, 各種機器の 整備点検と日月報の作成, などである.

このうち, 各管理所とも全員一斉に稼動するのは洪水 時の 2 項目であることはいうまでもない.

個別管理の系統図を図一2に示す.

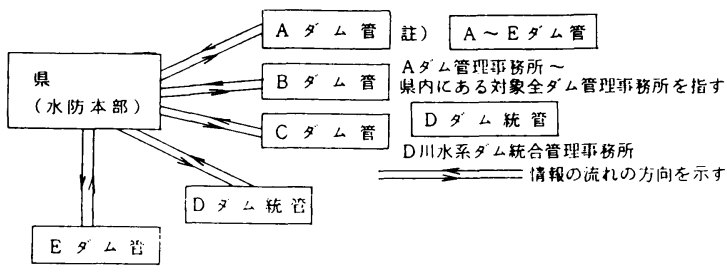

図一2 ダム個別管理系統図

b) 現状管理機能の分析

前述の業務を行う機能を分析した結果は表一1のとお りである.

この機能の運用を, 平常時と洪水時とに分類する. 両 者は洪水警戒体制を取った時点で区分される.
(1) 平常時の機能分担

洪水期，非洪水期を通じ恒常的業務で機能期間が最も 長い. 洪水時には応急的な整備点検しかできない各種機 器など, 本格的な修理整備を行うこと. さらに洪水時の 各種記録，洪水に関する資料の収集，整理，解析などで ある・

(2) 洪水時の機能分担

平常時に比べて管理業務は大幅に増大する，表一1の 管理機能のほとんどすべてが運用される．さらに，いつ 発生するか推定できない洪水を予想し常に準備と訓練を 行っていなければスムーズに対応できない.

\section{表一1 ダム管理所の機能}

\begin{tabular}{|c|c|c|}
\hline 機能項目 & 実 施 内容 & 供 \\
\hline （1）情報収㮐 & 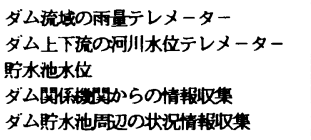 & \\
\hline $\begin{array}{l}\text { （2）晴轩云達及 } \\
\text { び交 }\end{array}$ & 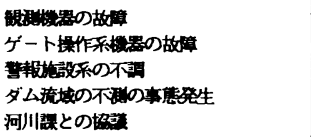 & \\
\hline $\begin{array}{c}\text { （3）整報及び } \\
\text { 通報 }\end{array}$ & 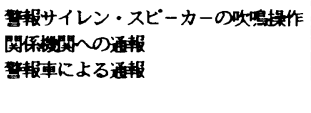 & 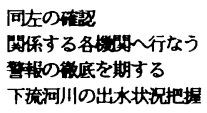 \\
\hline （4）情報処理 & 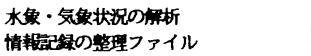 & \\
\hline (5) 半断 & 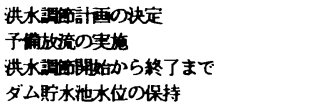 & \\
\hline （6）ゲート搢作 & $\begin{array}{l}\text { ゲート操作 } \\
\text { ゲート聞度 }\end{array}$ & \\
\hline 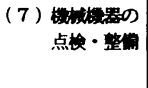 & 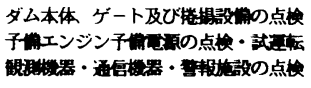 & $\begin{array}{l}\text { 洪水㭙の停雪を予想 } \\
\text { 望消、约3 0分間要する }\end{array}$ \\
\hline $\begin{array}{l}\text { （8）报等の整 } \\
\text { 㑋等 }\end{array}$ & $\begin{array}{l}\text { 日報・日詰の作成 } \\
\text { 月報の作成 } \\
\text { 記録军真の蝭影 }\end{array}$ & \\
\hline （9）訓研研侤 & 探作・計算・通等 & 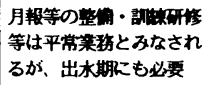 \\
\hline
\end{tabular}

\section{3. ダム群集合管理組織計画}

2.（1）で述べた諸点は，ダム建設が進む中でこのま までは管理機能を現状の水準に維持することすら困難に なって, ダム群の管理機能障害に発展するおそれが出て 来る.しかし，昨今の社会の要請は，さらに安全で確実 な生活環境を求めるもの゙で, 当然ダム管理もその線に そうものでなければならない. そこで, 現状管理の含む 欠点を補うように，次の方法で管理組織を計画する. 


\section{（1）単数集中型から複数集中型へ}

情報の集中, 異常時の即応, 実態把握の困難, 管理技 術レベル，職員配置等に要約される問題点は，管理ダム 数の増大による,いわば過密化の状態によるものである. 事実，管理ダム数が多くない時点では問題として起き なかったことを併せ考察すると，一点集中管理方式から 適当な規模への集中管理が望ましい。

そこで, (1)各機能活動上整合が取れ運用がスムーズで 組織上信頼が置けること, (2)故障, 異常事態等への対応 が迅速に取れること, (3)ダム本体, 下流域, 職員等の安 全が保たれること，(4)管理業務遂行上に必要な職員の確 保，技術水準の維持が図れること，以上の(1) (4)を条件 として図一3に示すようなシステムを計画した。

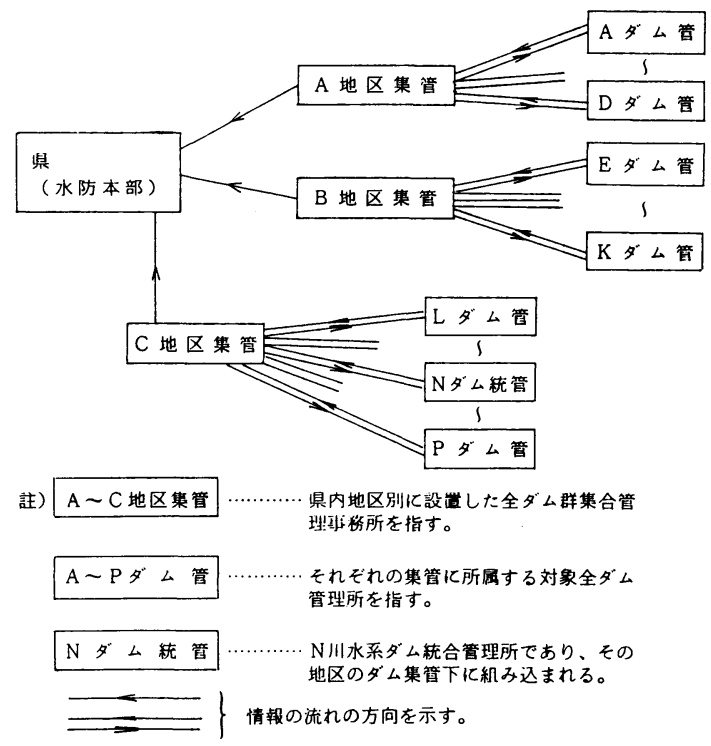

図一3 ダム集管系統図

これは県内をいくつかのブロックに分けて，その地域 内の数河川水系にあるダム群をまとめて管理するもの で，著者はこれをダム群集合管理システムと定義する.

このシステムは, ブロック内ダム群の管理組織と, そ れぞれの組織への機能分担，さらに機能運用にあたる人 員配置の 3 要素によって成立する.

管理機能障害に発展するおそれのある問題点はこれに よって十分に取り除き得るものである.

（2）ダム管理所とダム群集合管理事務所の機能分担

本システムの有用性は現方式の改善にあり, 特にシス テムの信頼度が高いこと, 安全性がさらに確保されるこ との 2 点が満たされる必要がある.そこでダム群集合管 理システムは平常時に管理業務の遂行が図られるととも に, 洪水時に計画を上回る大洪水や，その他の異常事態 が発生した場合でも的確に対応し得るものでなければな
らない。

基本として, 地域の中心に中枢組織のダム群集合管理 事務所（以下「集管」と略記する）を設置する.

さらに，集管の管轄下に，指令が中断するような場合 にもダム側で単独に洪水調節が一時的に行える最小限度 の判断と処理機能をもつダム管理所をダムごとに置く組 織とする。

そのうえで，それぞれの組織に対して機能分担を明確 にする. この機能分担は, 平常時と洪水時 2 つに分けて 行う.

a) 平常時の機能分担

ダム操作規則の定めや，実績などから恒常的業務とし て, 各種機器の点検保守, およびダム本体の点検, なら びに利水関連のゲート操作, 日常管理業務記録の整理等 が主である．洪水時との対比でみると，洪水に対する準 備作業とみなすこともできる。

平常時の機能分担を表一2に示す.

表一2 平常時の機能分担

\begin{tabular}{|c|c|c|c|}
\hline 能 & 名么首 理 所 & 通倍 & 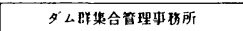 \\
\hline $\begin{array}{l}\text { 器の保守 } \\
\text { 点涣 }\end{array}$ & 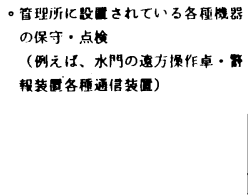 & $\leftarrow$ & 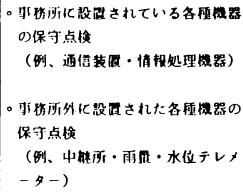 \\
\hline 纪䩮の整理 & 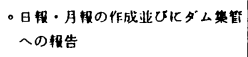 & $\longrightarrow$ & 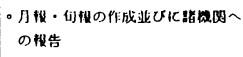 \\
\hline
\end{tabular}

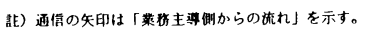

b) 洪水時の機能分担

ダム管理所が主体となって行う業務を，ダム流域なら びに同貯水池の周辺およびダム下流域の情報収集と, ゲート操作にとどめ, 洪水調節に関する処理, 判断等大 部分は集管で集中して行い，その実行をダム管理所に指 示することにする.

これによってダム管理所は自所の有する諸計器の能力 の範囲内において観測, 操作に専念することができる.

これはまた, ダム管理所と集管との連絡が不測の事故 のため，断たれた場合でも一時的にダム管理所において 洪水調節操作ができる最少の能力を有することとなり, 分散管理も可能なダブルチェック型となる.

一方, 集管では地域内各ダム管理所および気象台を始 めとし，隣接する土木事務所等関係他機関からの広域的 な情報を集め処理して降雨, 洪水に対し的確な判断を行 い指示する. さらに警報車の整備, 出動等洪水時に必要 な業務は集管に移し能率化する。

報告書 (月・日報および記録等), 警報発令なども集 管とダム管理所で照合することで正確度を増す。 
表一3 洪水時の機能分担

\begin{tabular}{|c|c|c|c|}
\hline 機 能 & 么 管 理 所 & 通倌 & 多么群集合管理事䂛所 \\
\hline 1 情叝收乗 & 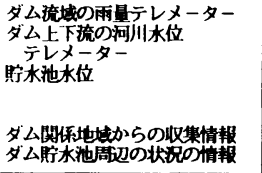 & $\begin{array}{l}\longrightarrow \\
\rightleftarrows \\
\rightleftarrows \\
\rightleftarrows\end{array}$ & 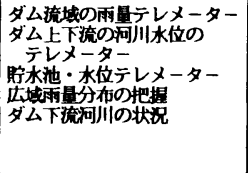 \\
\hline 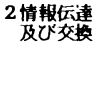 & 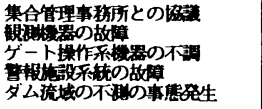 & $\leftrightarrow$ & ダム管理所との娪现 \\
\hline 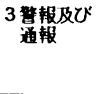 & 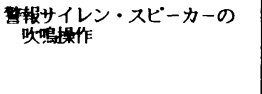 & $\longleftarrow$ & 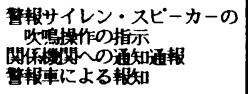 \\
\hline 4 情㫰处理 & 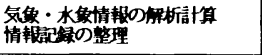 & $\leftarrow$ & 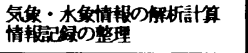 \\
\hline 5 半 & 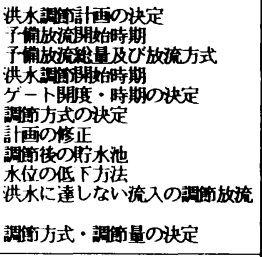 & 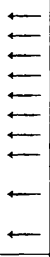 & 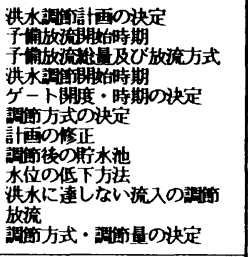 \\
\hline 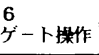 & 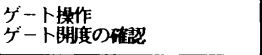 & $\rightarrow$ & ゲート開度の㴶彗 \\
\hline 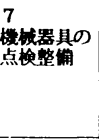 & 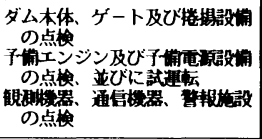 & & 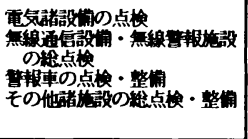 \\
\hline $\begin{array}{c}\text { 8年都等の } \\
\text { 整䇶等 }\end{array}$ & 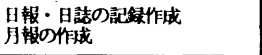 & & 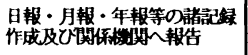 \\
\hline 9 数育訓蜮 & & $\leftarrow$ & 教育哰䁖 \\
\hline
\end{tabular}

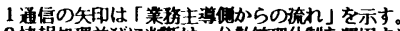

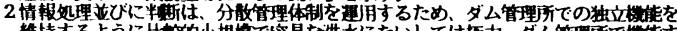

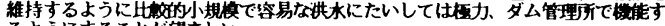
るようにすることが望ましい。

教育，訓練は平常時に集管でまとめて行うが，出水時 に，管内の管理所で実際に行う業務に参加させて熟練度 を上げることができる.

具体的な機能分担は表一 3 に示す.

c) 特殊ダムの取扱い

数多くの多目的ダムの中には, 当該地域における各利 水目的上の必要性，あるいは地形上の制約から洪水に際 し，集管下の他のダムと同一取扱いのできない場合も出 て来る.これらのダムについては, ダムの能力, 機能上 の特殊性を調査し，集管，あるいはダム管理所に別機能 を付加することにより対応する.

\section{（3）集合管理システム人員配置案}

ごく一般的には，重要な業務を処理する組織に対して 必要な人員は充足させるのは当然であると認識されてい る. 実際には, この常識が通用せず，人員増を伴うよう な場合は組織を改変することすら困難である.

一方，本システムは分担した機能を有効に運用して始 めて効力を発揮するものであり, 適切な配置なくしては 成り立たない。そこで現実に即した実際化の可能な人員
配置案を計画の中に取り入れる.

ダム管理所はダム近傍に設置し，連絡系等の異常事態 には単独でも機能できるものとすることは，すでに述べ たとおりである．現在，機器系の進歩が大きいので情報 処理や連絡には新しい機器の導入が図られている. しか し, 洪水調節の重要性から操作ミス，誤作動は防がなけ ればならず，このチェックと機器の保守，点検等は洪水 時のダム運用とともに比重は大きい.

そこで配置としては, まずダム管理所には, 情報収集, 同処理等のため土木技術者 1 名, 水門操作, 情報連絡, 機器保守のため電気系技術者または機器系技術者の 1 名 計 2 名構成とする.

次に，ダム群集合管理事務所であるが，統括責任者と して所長 1 名，管下のダムおのおのに対応する土木技術 者 1 名, すなわち各ダムとマンツーマンとする.

これと同数の警報車と出動する運転広報者を置き警報 の撤底を図る。

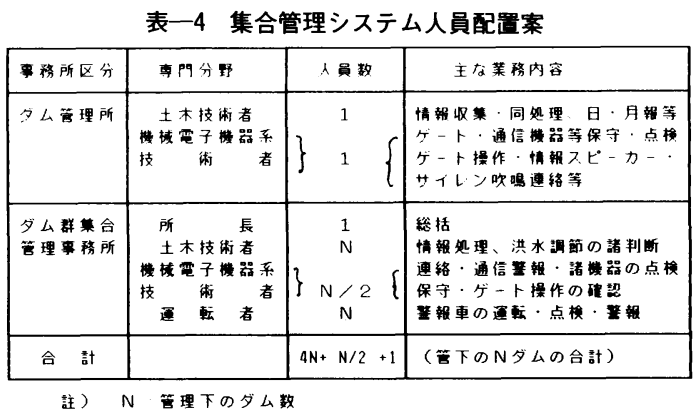

各ダムの水門の保守, 補修と, 機器, テレメータ一等 情報系とに対し，それぞれ管下のダム数の $1 / 4$ 名ずつ, 計 $1 / 2 （ 1$ ダム当たり）とする.これで機械, 電気系技 術者は 1 名で 2 ダム担当となる。

以上をまとめると表一 4 集合管理システム人員配置案 に示すとおりになる．特種なケースについては事情によ り配置を増す。

\section{4. 集合管理システムの適用例による検討}

組織，機能分担，人員配置によって構成される集合管 理システムが実際に発生する洪水に対し, 計画どおりの 対応が可能か，あるいは改善を要するかは，実施例をみ ない限り検証できない.

したがって,ここでは富山県内のダム群を対象にして， 過去に発生した洪水を用い, 本計画のシミュレーション を行った。 そのうえで修正を加え本計画を決定した。

\section{（1）富山県内の対象ダム群}

富山県のダム群を対象にした理由は以下のような点で ある. 同県はダム建設が盛んで, その数も急増しており, 
昭和 60 年代には県内の中小河川に 13 の補助ダムを築造 し，多目的使用する計画がある.うち現在すでに 9 ダム が完成し，管理に移っている5). 将来昭和 70 年代には 20 数個のダム群に増設する構想もあるなど, ダムの数 が多い.

同県の河川は急流が多く，したがってダムも急流河川 に建設されており，各ダムはいずれも貯留量が少ない.

流域面積も $20 \sim 50 \mathrm{~km}^{2}$ ほどのダムが多い．これを同 規模の流域面積をもつ全国平均と比貯留量を比べると $48.5 \%$ と半分以下の比貯留量しかない吕.このように 貯留量の少ないダムでは流域特性による影響も受けやす く,ゲート操作も頻繁でダム管理も難しい ${ }^{6)}$.

中小河川も県内一円に分布しており，しかも，補助ダ ムは 1 河川 1 ダムがほとんどで同一水系に 2 ダム設置す るものが少数あるだけであること，などである.

同県のダム群等の配置について図一4に示す.

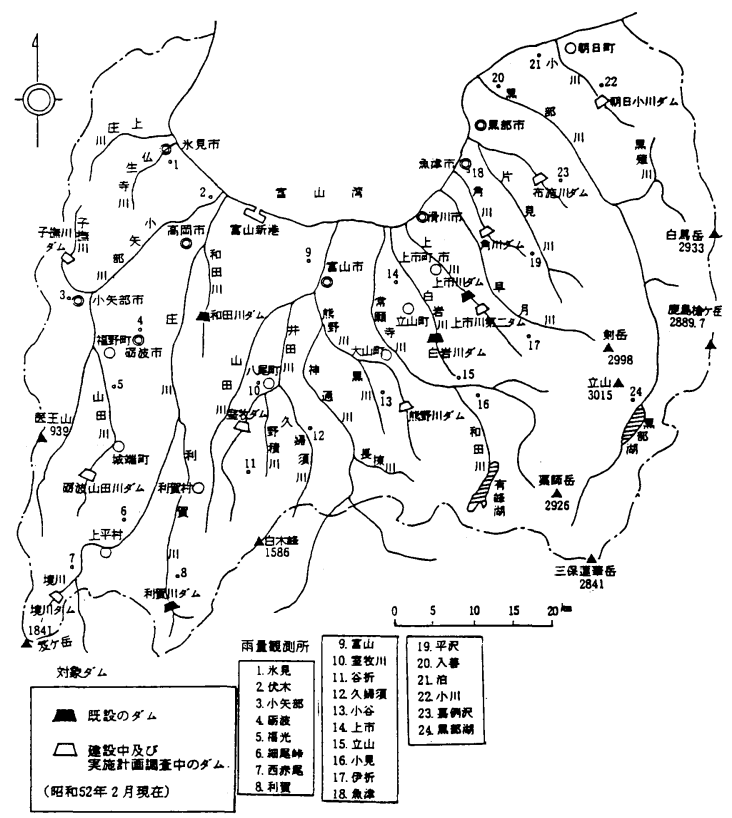

図一4 富山県のダムおよび雨量観測所位置図

\section{（2）集合管理ダム群の選定}

ダム群の選定は, ダムの設置されている河川流域を含 む 1 つの地域範囲を決定することであり, 本計画の基本 となる.したがってその適否はこの管理組織の機能維持, 向上の成否に大きな影響がある.

地域決定要件を, 地域特性, 管理実施機関, 基地から の管理可能域の 3 項に分ける.

a) 地 域特性

資料調査から流域, 水系,ならびに降雨特性など現況, 水文等による分類, 共通地域社会としての住民の認識な
どから共通性あるいは類似点が見出せる範囲地域を定 め, その地域にあるダム群をまとめる.

県の地域性を特徴づける要因に流域概要, 地質, 融雪 洪水，地すべり，土砂流出等がある。しかし，これらは ダム群を区分するまでの特徵はない。そこで洪水の直接 原因である降雨について調べる.

(1) 降雨の地域的分布の類型化

同県には既在資料として大正 2 年 10 月から昭和 30 年 7 月までの洪水時の日雨量線図があった。これを降雨の 地域分布 I とする。ささらに，比較的観測記録が整った昭 和 39 年から同 49 年までの洪水時の降雨を, 県農業気象 月報所収の全観測所 24 地点の記録から日雨量線図にし た.

これを降雨の地域分布 II とし，これらの日雨量線図か ら地域分類を行ったところ，次のようになった。

すなわち，全域型…県内全域に降る．平地型…山地部 に少なく平地部に多い. 東域型…県東部に偏る降雨型. 中域型…県中央部に集中する傾向の降雨. 西域型…県西 部に偏る降雨型.である.

発生状況を地域分布 I（大正 2 年〜昭和 30 年）と地 域分布 II（昭和 39 年〜昭和 49 年）に分けて示すと，表 一5になる。

表 -5 降雨の地域分布型比較

(क)

\begin{tabular}{|c|c|c|c|c|c|}
\hline 表 別迆域分布 & 全 域型 & 平 地 型 & 東 域 型 & 中 域 型 & 西 域 型 \\
\hline 降雨の地域分布 I & 53 & 0 & 18 & 9 & 20 \\
\hline$\prime \prime$ & 52 & 10 & 28 & 2 & 8 \\
\hline
\end{tabular}

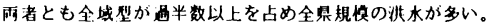

地形上から平野部は県中央部に多く、地域分布 I と地域分布 II とでは中域型と平地型 が 丁度入れ禁わった数值になっている、類似しているのでまとめ中域型と区分する。

これによると，全域型は県内一円となるので地域区分 から除くと，東，中，西の 3 区分が出てくる.

(2) その他の特性

計量することのできない特性の 1 つに共通社会の住民 認識がある. 富山市の西に尅羽山（標高 $76.8 \mathrm{~m}$ ）の低 い丘陵性の山があり，これより東を呉東，西を呉西とよ んで県内を 2 分した形になっている. 行政上の別は全く ないが，地域区分として住民の間に定着している.

\section{b）管理実施機関}

河川管理者以外でもダム建設も管理も可能であるが, これらを同一条件のもとに管理するにはいまだ解決すべ きことが多いので今回は補助ダムに限ることとする.

c) 管理可能範囲

ダムサイトは一般に遠隔地にあるので，基地となる集 管事務所は各ダムから交通体系上比較的均等距離にある 地方中心的な都市周辺に置くことにする．この場合，異 
常事態等の応援班の到達時間が問題となる．晴天時と異 なり荒天，または洪水時等で出動するケースには通常の 2 2 倍の時間を要する.そこで実際に所要時間を計測 し,さらに準備等の時間も算入し，この場合は 2 時間を 目標とする.

表一6 ダム群集合管理計画 ( 3 か所案)

\begin{tabular}{|c|c|c|c|c|c|c|}
\hline 迴间及Uダム名 & 所長 & 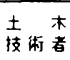 & $\begin{array}{l}\text { 植行 } \\
\text { 者 }\end{array}$ & 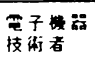 & $\begin{array}{l}\text { 票者 } \\
\text { 者地 }\end{array}$ & $s_{t}$ \\
\hline 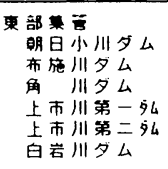 & 1 & $\begin{array}{l}5 \\
1 \\
1 \\
1 \\
2 \\
1 \\
1 \\
1\end{array}$ & 2 & $\begin{array}{l}1 \\
1 \\
1 \\
1 \\
1 \\
1 \\
1 \\
1\end{array}$ & 5 & $\begin{array}{r}14 \\
2 \\
2 \\
2 \\
5 \\
2 \\
2 \\
2\end{array}$ \\
\hline 小 㖕 & 1 & 12 & 3 & 7 & 6 & 29 \\
\hline 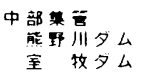 & 1 & $\begin{array}{l}2 \\
1 \\
1\end{array}$ & 1 & $\begin{array}{l}1 \\
1 \\
1\end{array}$ & 2 & $\begin{array}{l}7 \\
2 \\
2\end{array}$ \\
\hline 小 計 & 1 & 4 & 1 & 3 & 2 & 11 \\
\hline 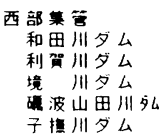 & 1 & $\begin{array}{l}4 \\
2 \\
1 \\
1 \\
1 \\
1\end{array}$ & $\begin{array}{l}1 \\
1 \\
1\end{array}$ & $\begin{array}{l}1 \\
1 \\
1 \\
1 \\
1 \\
1\end{array}$ & $\begin{array}{l}3 \\
1\end{array}$ & $\begin{array}{r}10 \\
3 \\
4 \\
3 \\
2 \\
2\end{array}$ \\
\hline st & 1 & 10 & 3 & 6 & 4 & 24 \\
\hline . & 3 & 26 & 7 & 16 & 12 & 64 \\
\hline
\end{tabular}

以上の条件を総合し, 集管 3 加所案 (東, 中, 西部) とし表一4により配置を行い，ダム群集合管理計画を立 案すると表一6のよおりである.

(3) システム・シミュレーション

ケーススタディーにおけるシステム・シミュレーショ ンは, 対象 13 ダムについて,運用を 2 段階に分けて行う. まず過去に発生した洪水の中から代表的洪水群を選び, これを用いて，各ダムで洪水調節を実行し，これによる 貯水池の水位変動を把握する.

次に，この貯水池の挙動と，たとえば計画を上回る長 時間の降雨とかの異常事態によ゙のように対応できるかな ど洪水時の集管システム稼動シミュレーションを行う.

以上を実行するため, 昭和 39 年〜昭和 49 年間の降雨 の中から 10 洪水を選ぶ。これは地域分布が, 全域, 地 域別，発生原因が偏らず全部にまたがるようにする.

また, 規模においては, 各年発生する程度のものから, 過去最大級となった降雨までの各規模のものとする.

このようにして選定した 10 洪水は表一7に示す.

表一7 シミュレーション対象洪水

\begin{tabular}{|c|c|c|c|c|c|}
\hline 洗水年月日 & s. 43.8 .28 & s. 44.8 .10 & s.45.6.14 & s.45.8.6 & s.46.6.11 \\
\hline 降雨鿌因 & 秋雨前線 & 低気正前湶 & 梅雨前線 & 前線 & 梅雨前線 \\
\hline 地域型 & 全㗪型 & 東些型 & 全城型 & 平她型 & 全城量 \\
\hline
\end{tabular}

\begin{tabular}{|c|c|c|c|c|}
\hline s. 46.7 .25 & s.46.9.5 & s. 47.7 .12 & s.47.9.16 & s. 19.8.25 \\
\hline 梅雨前楾 & 台風秋雨前線 & 低気开前隍 & 寒冾前線 & 台風 \\
\hline 東践型 & 全域型 & 全域型 & 全域型 & 全战型 \\
\hline
\end{tabular}

a）ダム貯水池の水位挙動シミュレーション

水位挙動シミュレーションでは設置されたダム群が発 生した洪水に対し, 洪水調節ルールに従って操作が行わ れた場合どのようであったかを水位変動にして示すもの である。

そこで上記各降雨に対し, 全ダムの流出量を算定し洪 水調節を行う.

使用する条件は次の(1)，(2)のとおりである.

(1) ダム流域からの流出量計算

13 ダムの中にはいまだ設置されていないダムを含む が，全ダムの流出量を時系列で表わす．流出量計算の方 法は数多くあるが，既設ダム以外は水文資料は十分とは いえないものが多い。そこで，補助ダム等で比較的よく 用いられる貯留関数法 ${ }^{10)}$ を用いて算定を行う.

(2) 洪水調節方式

調節方法は既設ダムについて現在用いている操作規 則 ${ }^{11)}$ による. 未設置ダムでは，各ダム計画の中の洪水調 節計画に基づき調節方式を定めて行う.

既設ダムが一定率〜一定量調節方式を取っているので 未設ダムにもこの方式を取り入れる. したがって調節方 式の諸元として, 以下のものが必要である. ○ダムの初 期水位, $\bigcirc$ 一定率調節開始流量, ○調節比率, $\bigcirc$ 一定量 調節開始流量, ○貯水上限（この水位に達した場合, 流 入量 $=$ 流出量とする)

表一8 ダム群集合管理シミュレーションに用いる諸条件

\begin{tabular}{|c|c|c|c|c|c|c|c|c|}
\hline \multicolumn{2}{|c|}{ :酒元象伴 } & 明日小川 & क节施川 & 解川 & 上市川第1 & 上市川第2 & 白安川 & 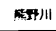 \\
\hline \multirow[t]{3}{*}{ 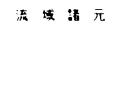 } & 流面相 $(\mathrm{km})$ & 34.6 & 13.9 & 16.2 & 44.7 7 & 38.7 & 240 & 39.8 \\
\hline & 洒骨 $(\mathrm{km})$ & 7.2 & 5.5 & 6.9 & 140 & 11.9 & 11.0 & 13.6 \\
\hline & $\mathbf{R}$ & 0.0958 & 0.1527 & 0.0839 & 0.0844 & 0.0983 & 0.0517 & 0.0882 \\
\hline \multirow{3}{*}{ 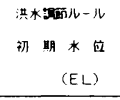 } & 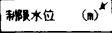 & ${ }^{*} 182.00$ & 265.00 & \$123.00 & 18880 & 276.00 & 129.20 & 31850 \\
\hline & 予相极流水位(a) & - & - & 120.25 & 184,00 & - & - & - \\
\hline & 晒屌水位 $\quad(\mathrm{m})$ & - & - & - & 176.00 & 275.5 & - & - \\
\hline \multirow{3}{*}{$\begin{array}{l}(E L) \\
(E L \text { 位上限 }\end{array}$} & y-开胁位（町 & - & - & - & - & - & 137.50 & - \\
\hline & 洪水珠洨水位(m) & 190.00 & 274.00 & 133.00 & - & - & - & 326.00 \\
\hline & 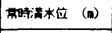 & - & - & - & 198.80 & 282.00 & - & - \\
\hline 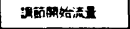 & $\left(m^{3} / \mathrm{s}\right)$ & 100.0 & 25.0 & 25.0 & 100.00 & 300.00 & 30.00 & 60.00 \\
\hline 是大放流 & $\left(m^{3} / \mathrm{s}\right)$ & 270.00 & 145.00 & 70.00 & 30500 & 330.00 & 240.00 & 300.00 \\
\hline 一定平极海の比事 & 1 & 0 & 0.59 & 0.29 & 0.71 & 0.12 & 0.68 & 0.40 \\
\hline 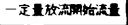 & $\left(m^{3} / \mathrm{s}\right)$ & 530.00 & 230.00 & 180.00 & 385.00 & 550.00 & 340.00 & 500.00 \\
\hline
\end{tabular}

\begin{tabular}{|c|c|c|c|c|c|c|c|}
\hline \multicolumn{2}{|c|}{ 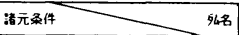 } & 豆牧 & 和田川 & 和的川 & 㖶山田川 & 暂川 & 子棈川 \\
\hline \multirow[t]{3}{*}{ 流 } & 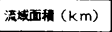 & 85.2 & 34.0 & 38.0 & 10.8 & 37.7 & 31.8 \\
\hline & 潄路 $(\mathrm{km})$ & 26.0 & 13.0 & 6.9 & 4.5 & 0.5 & 11.2 \\
\hline & $\boldsymbol{R}$ & 0.035 & 0.0173 & 0.0638 & 0.0622 & 0.0772 & 0.0277 \\
\hline \multirow{3}{*}{$\begin{array}{c}\text { 洪水溫儿ール } \\
\text { (EL) }\end{array}$} & 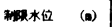 & 249.00 & 41.50 & 889.00 & 253.50 & 55600 & 100.40 \\
\hline & 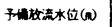 & 247.50 & 40.60 & 887.00 & - & - & - \\
\hline & 锂保水位 (m) & 246,00 & 41.50 & - & - & - & - \\
\hline \multirow{3}{*}{$\begin{array}{l}\text { 野水位上䧆 } \\
\text { (EL) }\end{array}$} & 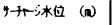 & - & 44. 10 & 895.50 & - & - & - \\
\hline & 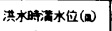 & - & - & - & 266.00 & 561.00 & 107.00 \\
\hline & 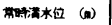 & 259.00 & - & - & - & - & - \\
\hline 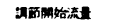 & $\left(m^{3} / \mathrm{s}\right)$ & 100.00 & 60.00 & 60.00 & 30.00 & 180.00 & 80.00 \\
\hline 悬大故流 & $\left(m^{3} / \mathrm{s}\right)$ & 265.00 & 120.00 & 200.00 & 40.00 & 250.00 & $170.0 \mathrm{c}$ \\
\hline 一定车放玨の比平 & 1 & 0.33 & 0.48 & 0.52 & 0.09 & 0.19 & 0.37 \\
\hline 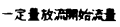 & $\left(m^{3} / \mathrm{s}\right)$ & 59500 & 185,00 & 330.00 & 140.00 & 540.00 & 390.00 \\
\hline
\end{tabular}

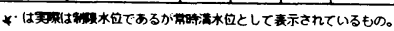


これらシミュレーションに用いるダムの諸数值を表一 8 に示す.

(3) 調節による貯水池の挙動

洪水調節シミュレーションはすべてのダムについて， ダムごとに，洪水ごとに行った。この一連のシミュレー ションの中で昭和 44 年 8 月 10 日洪水は全県下に及ん だ. 特に県東部では全ダムが洪水調節を行った。中でも 角川ダムは計画高水量以上が流入し，ダムも満水位に達 し, 流入量 =流出量の操作も行った，その変化は図一6 に例示する．全ダムに行った結果を表一9にまとめて示 す.

これによると, 最大級の昭和 44 年 8 月 10 日洪水以外 の 9 洪水では一定率調節を行ったダムもいくつかはあっ たが，いずれも満水位以下で安全に調節ができた。

また，調節開始流量の比流量が 2.0 以下のダムでは操 作頻度が多くなった。

シミュレーション対象期間内でも，つまり 10 年に 1 度は満水位に達するようなダムがあり，相当慎重な操作 が必要であることなどがわかる.

b) 管理機能稼動シミュレーション

前項では，本システムで調節ルールどおりに運用した

表一9 ダム群洪水調節による貯水位挙動シミュレーション結果

\begin{tabular}{|c|c|c|c|c|c|c|c|c|c|c|c|c|}
\hline \$ $\triangle$ 名 & 初期水位 & \begin{tabular}{|l|}
5.43 \\
8.28
\end{tabular} & \begin{tabular}{|l|}
5.44 \\
8.10
\end{tabular} & $\begin{array}{l}5.45 \\
6.14 \\
\end{array}$ & \begin{tabular}{|l|}
5.45 \\
8.6 \\
8
\end{tabular} & \begin{tabular}{|l|}
$s .46$ \\
6.11 \\
\end{tabular} & $\begin{array}{l}5.46 \\
7.25 \\
\end{array}$ & \begin{tabular}{|l|}
5.46 \\
9.5 \\
\end{tabular} & \begin{tabular}{|l|}
5.47 \\
7.12
\end{tabular} & $\begin{array}{l}5.47 \\
9.16\end{array}$ & \begin{tabular}{|l}
5.49 \\
8.25
\end{tabular} & 比施到 \\
\hline 胡的少么 & 粬樶水位 & & $*$ & & & & & & * & & & $\begin{array}{r}2.9 \\
15.3 \\
\end{array}$ \\
\hline 布地算 & 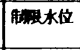 & & * & & & & * & $*$ & & & & $\begin{array}{r}1.8 \\
16.5\end{array}$ \\
\hline \multirow[t]{2}{*}{ 㓩川\$ } & 船眼木位 & & $\begin{array}{l}* * * \\
* * *\end{array}$ & & & $*$ & $*$ & $*$ & & & & \\
\hline & 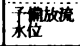 & & $\begin{array}{l}* * * \\
* * *\end{array}$ & & & * & $*$ & $*$ & & & & i1. \\
\hline \multirow{3}{*}{ 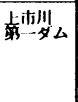 } & 坫时水位 & & $*$ & & & & & & & & & \\
\hline & 予放流 & & $*$ & & & & & & & & & \\
\hline & 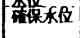 & & $*$ & & & & & & & & & \\
\hline \multirow{2}{*}{ 走南川 } & 粗樶水位 & & * & & & & & & & & & \\
\hline & 形栏水位 & & $*$ & & & & & & & & & \\
\hline 白岩少么 & 制明水位 & & $*$ & & & & * & * & & & & $\begin{array}{l}1.3 \\
4.2 \\
\end{array}$ \\
\hline 熋品少 & 秘明水位 & & * & & & & * & * & * & * & & 14.6 \\
\hline \multirow[t]{3}{*}{ 要牧乡人 } & 野的水位 & & & & & * & & & & & * & \\
\hline & 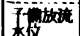 & & & & & $*$ & & & & & $*$ & \\
\hline & 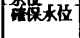 & & & & & * & & - & 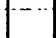 & 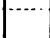 & $-\bar{*}$ & \\
\hline \multirow[t]{3}{*}{ 和(一时少 } & 制䁚水位 & & * & & & & * & & & & & \\
\hline & 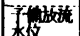 & & * & & & & $*$ & & & $\cdots$ & & \\
\hline & 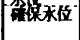 & & 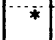 & & & & $*$ & & & & & \\
\hline \multirow{2}{*}{ 利罗川 } & 昉理水位 & * & * & * & * & * & * & * & * & * & * & \\
\hline & 乘位 & * & $*$ & $*$ & * & * & $*$ & $*$ & $*$ & $*$ & $*$ & 8.9 \\
\hline 波岁思 & 製相柆 & & & & & & & & & & & $\begin{array}{r}2.8 \\
13.0\end{array}$ \\
\hline 境川ダム & 野水位 & & & & & & & & & & & $\begin{array}{r}4.8 \\
14.3\end{array}$ \\
\hline 子繁川 & 制的㮛位 & * & & & * & & & & & & & $\begin{array}{r}1.3 \\
12.3\end{array}$ \\
\hline \multicolumn{2}{|c|}{$\operatorname{TOTAL} \underset{* * *}{* *}$} & $a_{0}^{2}$ & \begin{tabular}{|l|}
8 \\
${ }^{8}$ \\
\end{tabular} & $\begin{array}{l}1 \\
0 \\
0\end{array}$ & 20 & $\begin{array}{l}3 \\
0 \\
0\end{array}$ & \begin{tabular}{|l|} 
\\
0 \\
0
\end{tabular} & $\begin{array}{l}5 \\
0 \\
0\end{array}$ & $\begin{array}{l}3 \\
0 \\
0\end{array}$ & $\begin{array}{l}2 \\
0 \\
0\end{array}$ & $\begin{array}{l}2 \\
0 \\
0\end{array}$ & \\
\hline \multicolumn{4}{|c|}{ 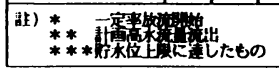 } & 此 & & & & $\overrightarrow{0}$ & 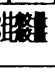 & & & 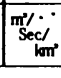 \\
\hline
\end{tabular}

場合貯水池に問題は生じないことがわかったそこで本 項では，本システムが表一9で示されるようにダム群を 作動させ得るかどうかについてシステム稼動シミュレー ションを行うものである

このためにまず予想される異常事態に取り得る方法を 設定しておき, 発生時に機能させるようにしておく.

(1) 異常事態と対応

人身事故等による管理所の機能停止，調節計画を超え る洪水, 水門操作系の故障, 予備電源, 予備エンジン等 設備の故障, 警報系の故障等には応援班を急派する.

たとえば地すべり等が発生し貯水池および流域内の異 常, 観測機器, 情報処理機器の故障等が起きた場合は, 集管側で流域内外の広域的資料から判断を下すとか，あ るいは事前にキャッチするよう努め，早期に指示する.

このほか, 通信系の故障には, 一時的にダム側で対応 し，復旧を急ぐとともに応援班を出動させる。などの設 定をしたうえで次の稼動シミュレーションに入る。

(2) 貯水位の変動とダム群集合管理の機能

大雨注意報発令により当該集管が警戒体制を取る時点 からダム管理所でも待機が始まる.

各集管ごとに，前節で行った水位変動図を用いダム別 に, 時間雨量, 流入流出，ダム水位曲線を発生する降雨 時間経過とともに対応させてゲート操作など管理業務を 進める.この際，記録から当該洪水により発生した地域 の災害に合わせたシステムの運用を行った。

表一10 ダム群集合管理稼動シミュレーション結果 (昭和 44 年 8 月 10 日洪水)

\begin{tabular}{|c|c|c|}
\hline 出 & 本 日 & S. 44.8 .10$. \\
\hline \multicolumn{2}{|c|}{ 降雨分布 } & 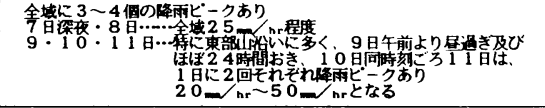 \\
\hline \multirow{2}{*}{ 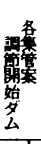 } & 2 ケ所赛 & 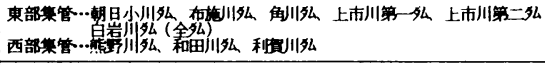 \\
\hline & 3ケ所案 & 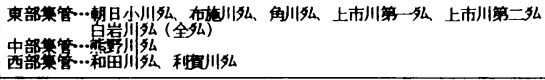 \\
\hline \multirow{10}{*}{ 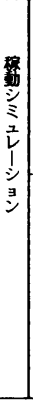 } & & ほぼ5昼效待漛 \\
\hline & 多㕕乵数䒤 & 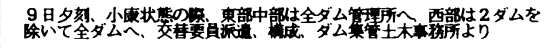 \\
\hline & & 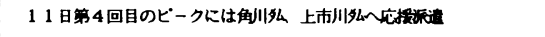 \\
\hline & & 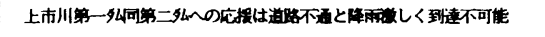 \\
\hline & & 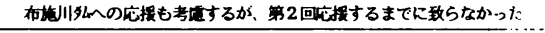 \\
\hline & \multirow{5}{*}{ ダム管理斦 } & 全ダム管理所 5 旦夜待機 \\
\hline & & 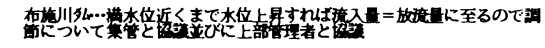 \\
\hline & & 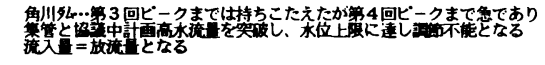 \\
\hline & & 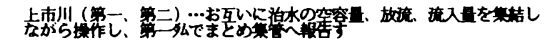 \\
\hline & & った外は特に閣题はない \\
\hline \multirow{3}{*}{\multicolumn{2}{|c|}{ 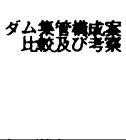 }} & 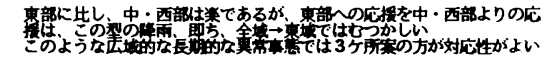 \\
\hline & & 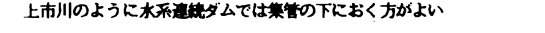 \\
\hline & & 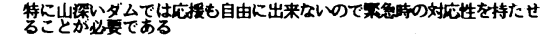 \\
\hline
\end{tabular}


この運用を対象 10 洪水に対して行い，その中で代表 的な昭和 44 年 8 月 10 日洪水についての結果を表一10 に示す。この表の稼動シミュレーションと考察の関連は 次章で述べる.

なお，表一 10 にある集管 2 か所案は 3 か所案の東部 はそのままで, 中部ダム群と西部ダム群を合わせ西部集 管とし東・西の 2 集管としたものである.

\section{5. 集合管理計画の決定}

各洪水ごとの稼動シミュレーションの結果，支障なく 対応可能でダム管理所とダム群集合管理事務所の機能と 配置は, ほぼ計画時の目的を達している.

しかし, 集合管理の基礎となる組織，すなわちダム群 の地域区分と機能を実行する配置人員の 2 項目につい て，下記のとおり修正を必要とすることとなった。

\section{（1）名么群の地域区分}

これについては表一10を用いて分析を行う.

同表の降雨分布および図一5 雨量の表示にみられる ように，数個の降雨ピークがあった．このため 5 昼夜に 及ぶ長期の警戒体制となった。

雨の降り始め 7 日夜から待機が続くので 9 日夕刻, 東 部, 中部全ダム, 西部の一部ダム管理所に交替要員を派 遣した．編成は事前に設定してあったが大規模動員と なった．さらに降雨も続き長期化したので 11 日に角川 ダムと上市川第 1 , 第 2 ダムへ再応援を行った. しかし, それまでの洪水で途中の道路が冠水, 流失する災害があ り上市川水系ではダムへ到達できず応援は引き返した。

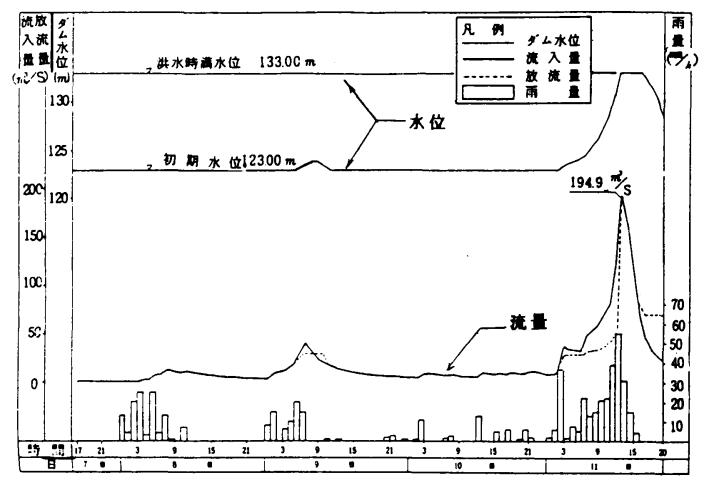

图一5角川ダム水位变就図 (昭和 44 年 8 月 10 日洪水)

全県的規模のこの洪水では全ダムともほとんど同時期 に 5 昼夜連続して洪水調節や待機を行った．このため東 部に比べると雨量の点では中・西部はやや少ないが中・ 西部から東部への応援はできない.

また，東部集管内では同時一斉に洪水調節運用を行っ ており，東部集管のみで応援対策は取れない，そこで同 集管と隣接土木事務所とにより応援班を編成し対応し
た.

このように応援対策が組みやすいこと，一定時間内に 目的ダムに到達しやすいことなどの点で集管 3 か所案が 2 か所案よりよいことがわかった.

他の洪水でも同様なことがいえ，全 10 洪水のうち 6 回まで同じようなケースがあった.

さらにシミュレーションでは，上市川水系のように 上・下流関連してダムがある場合は，2ダム統合管理し たうえで集管体制下におくことがよいこともいえる.

また西部集管では問題を生ずるまでは至らなかったが 岐阜県境にある境川ダムは隔遠地にあり管理所の強化を しておく必要があった.

\section{（2）人員配置計画}

配置案表一 4 によって行ったシミュレーションでも対 応稼動は可能であることがわかる．しかし，洪水が広範 で長期にわたることもあるので交替，応援の必要から人 員配置を修正しておいた方がよいこともわかった.

すなわち，応援要員はダム集管と関係土木事務所から 事前に立てた計画にそって編成する．原則としてダム管 理所と同数の 2 名とする. 集管外からの要員にはダム管 理経験者かあるいは定期的な管理訓練を受けた技術者を あらかじめリストアップしておき，その中から選択する.

しかし，応援班の熟練度を維持するためには，現に管 理を行っているダム集管の技術者をキャップにする必要 がある. 集管では $N+N / 2$ 名の機械，電気系と土木技 術者が洪水調節に従事している. 各ダム一斉に応援が必 要となった場合でも $N$ 名は各ダム担当として集管に残 るので，応援には $N / 2$ 名しか期待できないことになる. そこで全ダム応援班に 1 名あて集管職員を当てることが できるように集管に $N / 2$ 名を増員しておくこととする.

このようにして決定した修正配置案を表一11 に示す.

表一11 集合管理システム人員基本配贯東

\begin{tabular}{|c|c|c|c|}
\hline 票稀所区分 & 南阳分影 & 人虽政 & 主な羍稀内容 \\
\hline ダム管理的 & 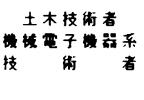 & $\begin{array}{l}1 \\
1\end{array}$ & 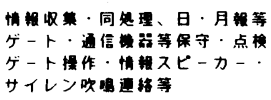 \\
\hline 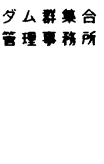 & 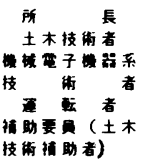 & $\left\{\begin{array}{l}1 \\
N \\
N \\
N\end{array} \mid 2 \quad\{\right.$ & 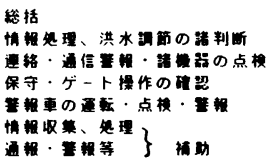 \\
\hline 合 計 & & $5 N+1$ & \\
\hline
\end{tabular}

注） $N$ 管理下のダム

\section{6. 結 論}

本論文は, 前章 2.（1）に示したダム数が増すことに よって生ずる問題点の解消を通じ，ダム管理の安全と信 
頼を高める目的で立てた計画が有効なことを論じたもの である.

本ダム群集合管理システムは, 組織, 機能分担, 人員 配置の 3 要素から成っている. 適切な地域区分と,チェッ クシステムが取れる機能分担を行った．特に著者はダム 管理に関する経験と現状から，熟練者を含む人員増がき わめて困難なことを認識したうえで, 実現化が図られ, かつ機能対応可能な配置を計画した.

その結果シミュレーションにより, 過度の集中による 障害の防止, 異常事態へのすみやかな対応, 情況把握の 確実, 管理技術の維持, 機器の保全などに大きな効果を 期待し得ることが明らかになった。ささらに，近年，降雨 観測レーダー網の整備, 気象衛星の情報, コンピューター の実用化などが一段と進み, 降雨や前線の動き, 台風進 路予測技術等に確かさを増してきている. そのうえ, 通 信, 交通体系の整備など社会資本の整備も本システムに とって有利に展開されつつあることから, 集合管理は広 く適用される可能性が大きいものである.

謝辞：本研究を進めるにあたり，終始ご懇切なご 指導と有益なご助言をいただいた東京大学工学部 高橋
裕教授をはじめ,資料収集等ご協力をいただいた関係者, ならびに関係機関, 特に富山県の各位に対し,ここに感 謝の意を表します.

\section{参文献}

1）建設省開発課資料，河川総合開発事業概要，昭和 61 年度 版.

2）（財）ダム技術センター, 日本のダム事業, 昭和 59 年 2 月, 同センター発行.

3）建設省河川局監修, 多目的ダムの建設, 第 2 巻, 土木施 工管理技術研究会, 昭和 52 年 2 月.

4) 高橋 裕ほか：土木工学大系, 自然環境論（III）, 彰国社, 昭和 55 年 11 月.

5）富山県資料, 富山県河川開発, 昭和 60 年度版.

6）大熊 孝: 日本における多目的ダムの特徵, 学術月報, Vol. 34, No. 7 .

7) 高橋 彌：ダム群集合管理システムに関する計画学的研 究, 昭和 61 年 3 月, 富士出版印刷.

8）富山県資料，日雨量線図集，大正 3 年 昭和 30 年.

9）富山県資料, 農業気象月報, 富山県内雨量資料, 昭和 39 年 昭和 49 年.

10） 3）と同じ, 第 1 巻.

11) 富山県規則, 富山県内の各ダムの操作規則.

(1986.11.12·受付) 